\title{
UKRAINIAN CULTURE: \\ INDIVIDUALISM OR COLLECTIVISM?
}

\section{Borysenko L. H.}

Frontier problems of modern psychology (conference proceedings). - Kherson: Gelvetika, 2016. - P. 59-63 


\section{СОЦІАЛЬНА ПСИХОЛОГІЯ, ПСИХОЛОГІЯ СОЦІАЛЬНОЇ РОБОТИ}

Borysenko L.H.

PhD,

Taras Shevchenko National University of Kyiv

\section{UKRAINIAN CULTURE: INDIVIDUALISM OR COLLECTIVISM?}

In contemporary cross-cultural psychology, individualismcollectivism is viewed as one of the most important dimension for comparing cultures. According to G. Hofstede, individualism is «a loosely knit social framework in which people are supposed to take care of themselves and of their immediate families only,» whereas collectivism «is characterized by a tight social framework in which people distinguish between in-groups and out-groups; they expect their ingroup to look after them, and in exchange for that they feel they owe absolute loyalty to it» [2, p. 45]. Thus in collectivistic cultures, people define themselves according to group membership, while people in individualistic cultures focus on personal rather than group preferences [19].

It is widely taken for granted that individualism is a striking feature of the Ukrainian national character. This was repeatedly stressed by some distinguished thinkers, such as M. Kostomarov, who illustrated individualistic behavior with examples of «the separation» of adult children from their parents [6], and D.Chyzhevsky, who characterized Ukrainian individualism as «the desire for freedom», which in certain cases «leads to self-isolation, the conflict with everything and everyone» [1]. Many interesting examples of individualistic behavior can also be found in Ukrainian proverbs and sayings.

At the same time, some authors argued for deep collectivistic roots of the Ukrainian culture. For example, it has been emphasized [8] that Ukrainian language even does not have a word equivalent to the English word of privacy, an underlying component of individualism. Historically, it is possible to reveal a mental and cultural drift from collectivistic to individualistic views in the Ukrainian Christian polemical literature of the $16^{\text {th }}$ century which after the annexation of Ukraine to the Russian Empire in the $17^{\text {th }}$ century, slowed down, and became passive and withdrawn [5]. 
The former Soviet Union is thought to be a collectivistic country [19], and this remains true at least in some regions of contemporary Russia [7]. In contrast, Ukraine, after the turn toward a democratic market society with the values of self-reliance and emphasis on individual freedoms, appeared to begin its quick move toward individualistic values. The study of the Schwartz's value orientations in Ukraine showed an increase in self-enhancement values (achievement, power) from 2004 to 2012 [20].

Since all these concepts are largely phenomenological in nature and/or based on indirect approaches, an important question arises: are there measurement instruments that can be used in order to reliably identify Ukrainian cultural orientation, understand the extent to which Ukrainians are more individualistic than collectivistic (or vice versa), and summarize how much their individualism differs from the individualism of contemporary Western societies? The answer is «yes» and I now address this important issue in details.

Attempts to quantify individualism-collectivism can be traced to 1970s. In his pioneering works, a Dutch social psychologist G. Hofstede introduced the comparison of cultures using six dimensions (values), including, among others, individualism [3]. Hofstede initially proposed an individualism index, with individualism and collectivism as the opposites of one continuum, but since 1990s individualism and collectivism have been often treated as two independent dimensions [9]. The next major advancement in this field was done by $\mathrm{H}$. Triandis, who viewed individualism-collectivism as one of the three cultural syndromes [19]. He proposed to split individualism and collectivism into vertical and horizontal subdimensions. Therefore the four combinations correspond to the four types of national cultures: vertical collectivism - seeing the self as a part of a collective and accepting inequalities within that collective; horizontal collectivism - seeing the self as a part of a collective, but stressing that all members of the collective are equal; vertical individualism - the conception of an autonomous individual and acceptance of inequality; horizontal individualism - the conception of an autonomous individual and stress on equality [e.g. 14].

Numerous cross cultural studies in dozens of countries have led to the conclusion that individualism is more prevalent in industrialized Western societies, while collectivism - in traditional Asian and African cultures. Example of vertical individualism is US corporate culture, whereas Sweden and Australia have a horizontal individualist culture; India is an example of a vertical collectivist culture, but such a specific 
culture as the culture of the Israeli kibbutz can be regarded as horizontal collectivist [3; 19].

The majority of the studies in Ukraine were carried out using Hofstede's Values Survey Module (VSM). Unfortunately, since the authors used different versions of VSM, their results are hardly comparable. Even worse, only three of those studies were truly crosscultural as they were based on the comparison of several countries. The individualism scores obtained therein were close to the average values, implying that Ukrainian individualism has, at best, a slight prevalence over collectivism [15-17]. Two more studies comparing different regions have resulted in contradictory findings: individualism was higher in Western Ukraine [12], or the difference was non-existent [10].

Three studies in Ukraine were based on other measures. A comparison of Ukrainian and U.S. women via a short 14-item survey developed by Triandis [18] showed that the former were more individualistic than the latter, although individualistic and collectivistic scores were not significantly different [11]. Another comparison of Ukrainians and Americans via a full 32 item measure of Singelis et al [14] demonstrated completely opposite results [8]. The latest study [4] (though samples were obtained in 1999) showed that the Western Ukrainian sample was more individualistic than the Eastern Ukrainian sample; the authors used four items from Singelis's 12-item independent self-construal scale [13].

Our own preliminary study using a modified measure of Singelis et al [14] suggests that an individualistic orientation is slightly more pronounced in all regions including Eastern and Western Ukraine, although the difference between individualism and collectivism scores is rather small and thereby requires deeper and more thorough investigation. Also, the vertical component is seen more often than the horizontal one.

Thus, despite the abiding myth of Ukrainian individualism, and contrary to expectation, attempts to measure Ukrainian individualismcollectivism have produced somewhat mixed conclusions. This is presumably due to the specificity of the social and age groups studied, which in turn may indicate a complex structure of this cultural syndrome in Ukraine. It is also likely that Ukraine, occupying an important position between individualistic Western Europe and mainly collectivistic Russia, has a "frontier culture», which is not easily classified as collectivistic or individualistic. In other words, while demonstrating individualistic ways of thought, Ukrainians may still preserve old collectivistic traditions, and 
also vice versa - while showing loyalty and cooperation, they may tend to avoid collective responsibility («my hut is on the edge of the village; I know nothing» - as a popular Ukrainian proverb says).

In conclusion, it is important to note that although there has been a long history of cross-cultural studies, Ukrainian culture has become the object of research only in the past two decades. The answers to many questions are still unknown, and much has to be done. But since the Ukrainian mentality experiences a coexistence of different, often conflicting, cultural norms and values, and since regional culture does indeed appear to matter in Ukraine, these characteristics make Ukraine an interesting target for further cross-cultural investigations.

\section{References:}

1. Chyzhevsky D. I. Essays on the history of philosophy in Ukraine / D. I. Chyzhevsky. - Kyiv, 1992. - 230 p. [in Ukrainian]

2. Hofstede G. Motivation, leadership, and organization: do American theories apply abroad? / G. Hofstede // Organizational dynamics. - 1980. No. 9. - P. 42-63.

3. Hofstede G. Culture's consequences: comparing values, behaviors, institutions and organizations across nations / G. Hofstede. - Sage Publications, 2001. $-622 \mathrm{p}$.

4. Kemmelmeier M. Greater self-enhancement in Western than Eastern Ukraine, but failure to replicate the Muhammad Ali effect / M. Kemmelmeier, O. Malanchuk // International Journal of Psychology. - 2016. - Vol. 51, No. 1. - P. 78-82.

5. Korkh O. M. The problem of individualism (a historical-philosophical analysis): abstract of thesis submitted for the degree of Doctor of Philosophical Sciences / O. M. Korkh. - Dnipropetrovsk, 2002. - 35 p. [in Ukrainian]

6. Kostomarov N. I. Two Russian nationalities / N. I. Kostomarov. Kiev-Kharkov: Maidan, 1991. - 72 p. [in Russian]

7. Latov Y. V. Discoveries and paradoxes of the ethnometric analysis of Russian business culture using Hofstede's methodology / Y. V. Latov, I. V. Latova // World of Russia. 2007. - Vol. 16, No. 4. - P. 43-72. [in Russian]

8. Mullen E. Comparing Americans' and Ukrainians' allocations of public assistance the role of affective reactions in helping behavior / E. Mullen, L. J. Skitka // Journal of Cross-Cultural Psychology. - 2009. - Vol. 40, No. 2. - P. 301-318.

9. Oyserman D. Rethinking individualism and collectivism: evaluation of theoretical assumptions and meta-analyses / D. Oyserman, H. M. Coon, M. Kemmelmeier // Psychological Bulletin. - 2002. - Vol. 128, No. 1. - P. 3-72. 
10. Pylypenko A. N., Lytvynenko N. I. Ukrainain mentality in Hofstede's research program / A. N. Pylypenko, N. I. Lytvynenko // Economics Bulletin. - 2015. - No. 2. - P. 9-19 [in Russian]

11. Shafiro M. V. Ukrainian and US American females differences in individualism/collectivism and gender attitudes / M. V. Shafiro, M. J. Himelein, D. L. Best // Journal of Cross-Cultural Psychology. - 2001. Vol. 34, No. 3. - P. 297-303.

12. Shestakovskyi O. Where do the cultural differences between regions lie? Experience of the use of Hofstede's methodology in Ukraine // Big wars, big transformations: historical sociology of the 20th century (conference proceedings). - Kyiv, 2014. - P. 224-226 [in Ukrainian]

13. Singelis T. M. The measurement of independent and interdependent self-construals / T. M. Singelis // Personality and Social Psychology Bulletin. - 1994. - Vol. 20, No. 5. - P. 580-591.

14. Singelis T. M. Horizontal and vertical dimensions of individualism and collectivism: a theoretical and measurement refinement / T. M. Singelis, H. C. Triandis, D. P. Bhawuk, M. J. Gelfand // Cross-Cultural Research. 1995. - Vol. 29, No. 3. - P. 240-275.

15. Spector P. E. Do national levels of individualism and internal locus of control relate to well-being: an ecological level international study / P. E. Spector, C. L. Cooper, J. I. Sanchez [et al] // Journal of Organizational Behavior. - 2001. - Vol. 22, No. 8. - P. 815-832.

16. Spector P. E. An international study of the psychometric properties of the Hofstede Values Survey Module 1994: a comparison of individual and country/province level results / P. E. Spector, C. L. Cooper, K. Sparks // Applied Psychology. - 2001. - Vol. 50, No. 2. - P. 269-281.

17. Temirbekova $Z$ h. Work related values: a comparison of four post-soviet countries / Z. Temirbekova, Y. V. Latov, N. V. Latova, Z. Temirbekov // Procedia - Social and Behavioral Sciences. - 2014. - No. 109. - P. 794-798.

18. Triandis H. C. Culture and social behavior. / H. C. Triandis. Mcgraw-Hill Book Company, 1994. - 330 p.

19. Triandis H. C. Individualism and collectivism / H. C. Triandis. Westview Press, 1995. - 284 p.

20. European Social Survey : [web site]. - 2002-2016. http://www.europeansocialsurvey.org (accessed 1 September 2016). 